\title{
ГРЕЧЕСКАЯ ГОСУДАРСТВЕННОСТЬ: ОТ МОНАРХИИ К РЕСПУБЛИКЕ
}

\section{GREEK STATEHOOD: FROM MONARCHY TO REPUBLIC}

E. Nazarova

Summary. The subject of this article is the formation of modern Greek statehood. And it is no coincidence, since Greece is a country with a rich history. It is not for nothing that it is considered the cradle of arts, culture and sciences, including legal ones. Greece (E $\lambda \lambda \dot{a} \delta a$, Hellada or Hellas) - a state located on the Balkan Peninsula in southern Europe, is a unitary power with a form of government in the form of a parliamentary Republic. The President of the country is elected every five years by the Parliament and is the head of state, while the Prime Minister is considered the head of government. The Greek government is represented by the Cabinet of Ministers, which is the highest collective decision-making body in matters of state, which includes: The Prime Minister, Ministers, Deputy Ministers and Ministers without portfolio. When writing this work, comparative-analytical and historical-theoretical research methods were used. The article provides a detailed and detailed analysis of the events that became the basis for the formation of modern Greece, as we know it today. The paper examines the political forces, parties and legal institutions that directly influenced the formation of the Greek republican form of government.

Keywords: Greece, statehood, monarchy, Republic, Constitution, legal state.

\author{
Назарова Екатерина Александровна \\ К.и.н., доцент, Краснодарский университет МВД \\ Poccuu \\ nazarova.prosya@yandex.ru
}

Аннотация. Предметом исследования данной статьи выступает становление современной греческой государственности. И не случайно, так как Греция - страна с богатейшей историей. Не зря ее считают колыбелью искусств, культуры и наук, в том числе и юридических. Сейчас Греция

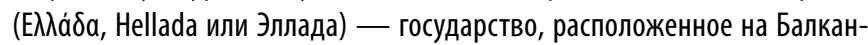
ском полуострове на юге Европы, является унитарной державой с формой правления в виде Парламентской Республики. Президент страны избирается каждые пять лет парламентом и является главой государства, в то время как главой правительства считается премьер-министр. Правительство Греции представлено Кабинетом министров, являющимся высшим органом принятия коллективного решения в вопросах государства, В который входят: премьер-министр, министры, заместители министров и министры без портфеля. При написании данной работы использовались сравнительно-аналитический и историко-теоретический методы исследования. В статье развернуто и детально анализируются события, которые стали базой для становления современной Греции, какой мы ее сегодня знаем. В работе исследуются политические силы, партии и правовые институты, которые непосредственным образом повлияли на формирование греческой республиканской формы правления.

Ключевые слова: Греция, государственность, монархия, республика, Конституция, правовое государство.

Нельзя не отметить роль православия в становлении современной греческой государственности. На уровне законодательства проявляется влияние греческой православной церкви. Бочков П.В. утверждает, что революционные события в Османской империи и последовавшая за ними активная борьба греков за национальное возрождение и свободу подтолкнули православную греческую иерархию искать союзников и защитников на Западе [2, стр. 81].

Основную идею представительных органов Греция заимствовала из Европы, применив ее, однако, с ранним введением избирательного права и учреждением однопалатного парламента. В Греции в тот период не было такого класса населения, как буржуазия, что препятствовало становлению либеральных взглядов в государстве. Это была еще одна особенность формирования представительных институтов в стране, отличная от европейского опыта. 
В целом национально-освободительная война привела к становлению Греции, как самостоятельного и независимого государства, от провинции Османской империи. Впервые подобие представительных органов было созвано в период освободительной войны и представляло собой Национальное собрание. На первом такой собрании был принят законодательный акт, который получил название Органический Статут - первая Конституция Греции. Нельзя сказать, что это был неизменный документ. Уже на втором собрании в него были внесены поправки. Статут был разработан на основе конституции эпохи Великой французской революции. Нужно отметить, что Статут фактически не отражал реальное политическое и социальное положение вещей в Греции, однако, на его основе были разработаны дальнейшие Конституции страны, он заложил основы греческой государственности. Например, статут закреплял разделение законодательной и исполнительной власти.

Следующая Конституция была приняла на Тризинском национальном собрании в 1827 году. Эта Конституция была разработана на основе Конституции США. В ней также был закреплен принцип разделения власти, главой исполнительной власти назначался президент, законодательной - парламент. Президент по данной конституции имел право отлагающего вето и был наделен широкими полномочиями. Примечательно, что кабинет министров был ответственен в своей работе перед парламентом.

В этот период Греция была признана на мировой арене как независимое государство Англией, Францией и Россией. Как мы можем видеть из исследований историков, в 1830 г. три великие державы - Англия, Франция и Россия - подписали Лондонский протокол, который определил статус Греческого государства, а в 1834 г. Афины были объявлены его столицей [3, стр. 107]. Однако, Греции все же пришлось изменить свой политический строй на монархический под давлением покровительствующих держав, что привело к отбрасыванию парламентской республики на несколько шагов назад. С 1835 по 1843 Греция была абсолютно монархическим государством. Меликов А.В. пишет, что в 1834 г. королевский двор перебрался в Афины, окончательно закрепив за городом столичный статус [4, стр. 39].

Несмотря на то, что причины свершившейся в 1843 году революции различны, факт остается фактом - монархия была повержена, в Греции принята новая Конституция, вновь во французских традициях. В этот раз исполнительная власть сосредоточилась в руках короля, он сам назначал себе министров, которые отвечали перед парламентом и перед ним. Законодательная власть была сосредоточена в руках парламента, состоящего из двух палат. Король, в свою очередь обладал правом законодательной инициативы, имел решающее слово в принятии законов, мог распускать парламент. Парламент состоял из верхней палаты - Сената, и нижней - Палата Представителей.

В Палате представителей участвовали 80 депутатов, которые избирались на 3 года. В Сенате было 27 человек изначально, но король имел право увеличить его еще на 13. Сенаторы назначались пожизненно, для них вводились определенные должностные и возрастные требования.

Законопроект принимался в три этапа. Сначала его принимала нижняя палата парламента, потом он проходил одобрение Сената. На третьем этапе окончательное решение относительно судьбы законопроекта принимал король. Такая система представляет собой классическую монархическую республику и сужает полномочия парламента. Принцип разделения властей был не до конца претворен в жизнь, поскольку законодательная и исполнительная власть почти в полном объеме находились в руках короля.

Однако, представительные институты впервые за последние 10 лет смогли получить хоть какое-то развитие. Король всячески мешал развитию и работе парламента, назначая оппозиционное ему правительство. Это было крайне негативным явлением, поскольку доказано, что правительство не раз подтасовывало результаты парламентских выборов. Сам король не раз менял состав Сената, несмотря на то, что должности там назначались пожизненные. Все это только накаляло ситуацию и мешало реальной работе государственных органов.

Результатом такой политики стало свержение короля, возведение на трон нового монарха и принятие новой Конституции. Теперь парламент стал однопалатным. Сенат был ликвидирован. Снова вернулось всеобщее избирательное право. В целом были расширены парламентские полномочия и упразднены некоторые полномочия короля, что ограничило его власть, а Грецию вновь направило в республиканское русло.

Единственным недостатком данной Конституции стал тот факт, что король мог назначать министров без согласия парламента. В 1875 году этот пробел был упразднен и в Конституцию было добавлено положение о необходимости выражения вотума доверия парламентом текущему правительству. До этого времени, не смотря на смену монарха, государственный аппарат работал все также некорректно: правительство занималось подтасовкой выборов, парламент и правительство соперничали друг с другом, парламент отправлялся в отставку при расхождении во взглядах с королем. 
Достижение компромисса между королем и парламентом было достигнуто стараниями талантливого политического деятеля Х. Трикуписа. Этот человек занимался реорганизацией государственного аппарата управления, борьбой с коррупцией, стимулированием развития экономики и прочими важными направлениями внутренней политики. Однако, будучи человеком, он не смог завершить все свои начинания, из-за чего острый политический и экономический кризис в Греции стал неизбежен.

В результате население поднялось на восстание, в котором участвовали военные. Так к власти пришел молодой политик Э. Венизелос и была разработана Конституция 1911 года. Он выступал против того, чтобы Северный Эпир был передан албанскому государству [5, стр. 123].

Процедура принятия закона по этому документу была гораздо проще, чем раньше. Кандидатом в депутаты мог стать молодой человек в возрасте 25 лет (ранее 30). Был расширен список лиц, которые не могли вообще избираться на депутатские должности. К ним относились военные, а также представители экономического сообщества, чья деятельность была важна для государства. Впервые была создана некая избирательная комиссия (независимая судебная инстанция), что было вызвано необходимостью борьбы с фальсификацией выборов [6, стр.120].

Проблемы текущей системы возникли, когда парламент и монарх не смогли сойтись во мнении об участии Греции в Первой Мировой Войне. Этот вопрос стал причиной серьезного конфликта между парламентом и королем, в результате которого страна раскололась на два государства - во главе с парламентом и во главе с королем. Раскол был настолько серьезным, что даже после воссоединения, в государстве долгое время существовали два политических лагеря - венизелисты и антивенизелисты.

Итак, в итоге Греция приняла участи в Первой Мировой Войне, разгромно ее проиграв. Провальный проигрыш только усилил конфликт и политический кризис внутри страны. В результате, король был вынужден покинуть страну вместе с его наследниками. Следующий монарх провозгласил Грецию республикой в 1924 год.

В результате дальнейших политических преобразований в Грецию вернулся двухпалатный парламент. В Палате представителей было 250 человек, избравшихся на 4 года тайным всеобщим голосованием. В Сенате было 120 человек со сроком полномочий на 9 лет, но состав Сената обновлялся каждые три года. Решающее слово при принятии закона было в Палаты пред- ставителей. Правительство формировалось парламентским большинством.

Через 6 лет, к началу 1930-х г.г. экономика Греции была сильно ослаблена мировым кризисом, на горизонте возникла серьезная угроза для благополучия страны. Однако, Конституция не предусматривала вмешательства государства в экономику, чего невозможно было избежать в условиях кризиса. В результате нормы Конституции постоянно нарушались, что привело к политическому кризису, после чего в стране произошла реставрация монархии. Премьер-министр получил диктаторские полномочия. В результате такого правления государственный аппарат был укреплен, а политический кризис прекращен. Однако, вся оппозиция в стране была подавлена [7, стр. 311].

Такое положение вещей продолжалось до Второй Мировой Войны и оккупацией страны фашистами. В Греции Вторая Мировая Война перетекла в гражданскую, из которой страна смогла выбраться только к 1949 году. Как отмечает Калинин А.А., в 1944-1946 гг. В Греции вызревал гражданский конфликт, который явился результатом синергии внутренних и внешних факторов [8, стр. 72].

В 1952 году была принята новая Конституция, которая не меняла существенно текущий политический строй. Нововведением по ней было предоставление избирательного права женщинам. Избирательное право закреплялось не как право граждан, а как их обязанность перед государством. Государство стало провозглашаться королевской республикой. Полномочия парламента оставались прежними. Исполнительная власть получила право издания указов, которые имели силу законодательного акта.

В 1963 года вновь произошло обострение политической ситуации в стране и были предприняты очередные шаги к внесению поправок в Конституцию. Поправки так и не были приняты, в 1965 году разразился новый политический кризис между монархом и парламентом. В результате в 1967 году была установлена семилетняя военная диктатура.

Итак, после окончательного падения диктатуры в 1974 году правительство национального единства провело референдум о судьбе монархии. 70\% населения проголосовали против монархической формы правления. В результате проведенных в дальнейшем выборов к власти пришла партия Новая Демократия. Результатом всех преобразований вновь стала новая Конституция.

Актуальной политической проблемой современности оставались конфликты между законодательной 
и исполнительной властью. В новых условиях не могли найти общий язык президент и парламент Греции. Основной причиной конфликта в этот раз стал вопрос о возможности регулирования работы парламента президентом. Данная проблема так и не нашла своего разрешения, из-за чего часть политических сил страны проигнорировало голосование за новую Конституцию.

Однако, в дальнейшем новый строй и система управления работали, как часы. При правлении партии Новой Демократии правительство парламента и президент придерживались единого политического курса, что позволяло претворять в жизнь важные социально-экономические программы и развивать внутренние силы государства.

В 1981 г. к власти пришла иная политическая сила левоцентристское ПАСОК (Всегреческое Социалистическое Движение), уже не ориентировавшееся на президента. Тем не менее смена власти не повлекла за собой радикального пересмотра основ политического строя, однако в 1985-1986 гг. ПАСОК настояло на внесении некоторых изменений в Конституцию. Эти изменения законодательно закрепили практику взаимоотношений между президентом и парламентом, фактически сложившуюся в предшествующее десятилетие. Важнейшим изменением было значительное ущемление полномочий президента республики по регулированию деятельности парламента.
Таким образом, политический строй Греции с тех пор представляет собой нечто среднее между президентской и парламентской республикой. Масштабные изменения в Конституцию были внесены в ходе конституционной реформы 2001 г.: модификации подверглись 79 статей. В результате были расширены права и свободы граждан, урегулированы некоторые вопросы политической деятельности, внесены поправки, необходимые для дальнейшей интеграции страны в Евросоюз. Основы политического строя страны изменений не претерпели.

В целом в Греции существует достаточно развитый механизм влияния гражданского общества на государство, что позволяет говорить о демократическом политическом режиме. Основы этого механизма заложены в Конституции. Одной из важнейших его составляющих является парламент, представляющий собой и орган власти, и канал влияния на нее политических партий и других групп интересов. Влияние православия отмечается и в современной Конституции [9], и в том факте, что депутаты парламента Греции при вступлении в должность приносят клятву религиозного содержания [10, стр. 196]. Другими осями греческого государства являются правительство и президент республики. Конституцией определяются полномочия каждого из компонентов государственной системы и порядок отношений между ними. Кроме того, Конституция предусматривает серьезные гарантии стабильности этой системы.

\section{ЛИТЕРАТУРА}

1. Ерёмин В.С. Греция глазами обозревателей «The Edinburgh Review» в 1802-1821 годах // История и историческая память. 2015. № 11. С. 116-123.

2. Бочков П.В. «Традиционная Православная Церковь Греции и диаспоры»: история возникновения и современное состояние // Научный вестник Арктики. 2018. № 3. С. 80-84.

3. Бибикова 0. Мусульмане Греции // Россия и мусульманский мир. 2015. № 7 (277). С. 103-140.

4. Меликов А.В. Конституционно-правовой статус города Афины в качестве столицы Греции с 1832 года: совпадение или историческая справедливость? // Наука. Общество. Государство. 2020. Т. 8. № 3 (31). С. 37-45.

5. Улунян А.А. Балканские национально-государственные автономии накануне и во время Первой Мировой Войны // Исторический вестник. 2014. Т. 9. № 156. C. 122-139.

6. Рубаник, В.Е. История государства и права зарубежных стран: Учебник для вузов. Стандарт третьего поколения / В.Е. Рубаник.- СПб.: Питер, 2018. 544 c.

7. Рубаник, В.Е. История государства права зарубежных стран: Учебник для вузов. / В.Е. Рубаник.—СПб.: Питер, 2017. - 544 с.

8. Калинин А.А. От гражданской войны к политической стабилизации: американское участие во внутриполитических процессах в Греции в 19491952 гг. // Вестник Вятского государственного гуманитарного университета. 2013. № 3-1. С. 77-87.

9. Конституция Греции [Электронный ресурс] URL: http://www.hri.org/MFA/syntagma/artcl25.html\#P1 (дата обращения 27.11.2020).

10. Морозова Л.А. Реализация прав человека в поликонфессиональном обществе // Социально-экономические явления и процессы. 2017. Т. 12. № 2. C. 195-201. 